\title{
KAJIAN PEMENUHAN KEBUTUHAN AIR MINUM UNTUK MASYARAKAT DI KAWASAN SEMI-ARID INDONESIA (A Study on Fulfillment of Drinking Water Need of People in Semi-Arid Areas in Indonesia)
}

\author{
Jakobis Johanis Messakh $^{1^{*}}$, Arwin Sabar ${ }^{2}$, Iwan Kridasantausa Hadihardaja ${ }^{3}$ \\ dan Alex Abdi Chalik ${ }^{4}$ \\ ${ }^{1}$ Program Studi Teknik Bangunan, Universitas Nusa Cendana, Jalan Adisucipto, Kupang, 85111. \\ ${ }^{2}$ Kelompok Keahlian Teknologi Pengelolaan Lingkungan, Fakultas Teknik Sipil dan Lingkungan, \\ Institut Teknologi Bandung, Jalan Ganesha No. 10, Bandung, 40132. \\ ${ }^{3}$ Kelompok Keahlian Teknik Sumber Daya Air, Fakultas Teknik Sipil dan Lingkungan, \\ Institut Teknologi Bandung, Jalan Ganesha No. 10, Bandung, 40132. \\ ${ }^{4}$ Kementerian Pekerjaan Umum dan Perumahan Rakyat Republik Indonesia, \\ Jalan Patimura No. 20, Jakarta, 12110.
}

*Penulis korespondensi. Tel: 081339405901. Email: yapmessakh@gmail.com.

Diterima: 20 Maret 2015

Disetujui: 29 April 2015

\begin{abstract}
Abstrak
Kawasan Kota Kupang dan sekitarnya saat ini berkembang menjadi pusat perekonomian, pendidikan dan sosial budaya di NTT, dengan laju permintaan kebutuhan air minum yang tinggi. Tantangan penyediaan air minum semakin besar, karena daerah tersebut merupakan kawasan semi-arid di Indonesia yang memiliki keterbatasan ketersediaan dan kontinuitas air dari berbagai sumber air yang ada. Penelitian ini bertujuan untuk menganalisa pemenuhan kebutuhan air minum bagi masyarakat di kawasan semi-arid Indonesia, khususnya Regional Kupang, tahun 2015-2035. Penelitian dibagi atas tiga tahap, yakni tahap pertama mengkaji proyeksi laju permintaan air minum tahun 2015-2035, tahap kedua melakukan identifikasi potensi sumber air tersedia, dan tahap ketiga mengatur skenario pemenuhan kebutuhan air minum. Hasil penelitian menunjukkan bahwa, potensi sumber air yang ada, sulit untuk memenuhi kebutuhan air minum pada rentang waktu perencanaan 2015-2035, khususnya mulai tahun 2019 dengan target pencapaian pelayanan air minum harus mencapai $100 \%$. Untuk mengatasi hal ini maka, paradigma pengelolaan sumber daya air untuk keperluan multisektor perlu disesuaikan menurut kekhasan kawasan semi-arid, dengan prioritas utama untuk kebutuhan air minum. Potensi curah hujan yang terjadi perlu dioptimalkan pemanfaatannya sebagai sumber air baku, melalui pembangunan waduk, sarana penampungan air hujan lainnya dan disertai upaya konservasi. Penghematan penggunaan air sesuai kebutuhan dan kearifan lokal daerah, serta pengaturan prioritas daerah pelayanan untuk sistem perpipaan air minum, merupakan strategi lainnya yang bisa dilakukan. Penggunaan air tanah yang merupakan sumber air baku utama, harus dikendalikan dengan mempertimbangkan daya dukung lingkungan.
\end{abstract}

Kata kunci: air baku, air minum, pengelolaan, semi-arid, sumber air.

\begin{abstract}
Kupang and its surrounding region are currently developing into a center of economy, education and socioculture in the NTT province, with a high rate of demand for drinking water. The challenge to provide drinking water supply has become greater and greater due to the fact that the area belongs to the semi-arid Indonesian region with limited water availability and continuity of the existing water sources. This study aims to analyze the fulfillment of the need for drinking water of the people in the semi-arid region of Indonesia, particularly in the city of Kupang and its surrounding, for the years of 2015-2035. The research was divided into three stages, i.e. the first stage, which examines the projected rate of the demand for the drinking water in 2015-2035, the second stage, which identifies potential sources of available water, and the third stage, which sets the scenario for providing drinking water supply. The results showed that it was difficult for the existing water sources to fulfill the need for the drinking water in the planned period of 2015-2035, especially starting from 2019, with the target of achieving 100\% drinking water services. To overcome the above-mentioned problem, it is deemed necessary to adjust the paradigm of the water resource management for the purpose of fulfilling the multi-sector needs according to the peculiarities of the semi-arid region, with drinking water needs as the main priority. The utilization of the potential rainfall needs to be optimized as a source of raw water through the construction of both dams and other means of rainwater harvesting, and conservation. Efficient use of water as required and local wisdom of the region, as well as setting priorities for the service area of drinking water piping systems, are other impending strategies. The use of ground water as the main source of raw water in the study area should be controlled by taking into consideration the environmental supporting capacity.
\end{abstract}

Keywords: drinking water, management, raw water, semi-arid, water source. 


\section{PENDAHULUAN}

Kota Kupang dan sekitarnya adalah bagian wilayah propinsi Nusa Tenggara Timur (NTT) yang merupakan kawasan semi-arid di Indonesia, sebagaimana dipetakan oleh United Nations Environment Management Group (Anonim, 2011). Sebagai kawasan semi-arid, daerah ini memiliki kekhasan iklim dan lingkungan dibanding wilayah lain di Indonesia. Menurut badan dunia Food and Agriculture Assosiation, iklim semi-arid adalah iklim daerah yang menerima curah hujan lebih rendah dibandingkan dengan evapotranspirasi potensial. Kawasan semi-arid merupakan bagian dari tiga zona kawasan arid dunia yakni hyper-arid, arid dan semi-arid. Total kawasan dunia yang tergolong hyper-arid sekitar 4,2\%, kawasan arid $14,6 \%$ dan kawasan semi-arid 12,2\%, dengan demikian sekitar 31\% kawasan di dunia merupakan daerah kering (Anonim, 1989). Hasil penelitian Messakh dkk. (2013) di DAS Tilong Kabupaten Kupang menunjukkan bahwa, kawasan tersebut merupakan daerah yang beriklim semi-arid, curah hujan berkisar $1.500 \mathrm{~mm}$ per-tahun, jumlah hari hujan 80 hari per-tahun dalam rentang waktu tiga sampai empat bulan, dan sisanya adalah musim kemarau delapan sampai sembilan bulan. Tingkat penguapan sangat tinggi dengan nilai evapotranspirasi potensial $2.600 \mathrm{~mm}$ per-tahun. Koefisien ketersediaan air tahunan sebesar 0,588 sehingga menjadi tantangan besar bagi keberlanjutan ketersediaan air di daerah tersebut.

Mengingat bahwa akses terhadap air merupakan hak dasar bagi manusia maka, penyediaan air minum bukan saja menjadi agenda nasional, namun juga menjadi agenda dunia, dengan dicanangkannya deklarasi Millenium Development Goals (MDGs). Target MDGs bidang air minum tahun 2015 yakni persentase rumah tangga dengan akses berkelanjutan terhadap sumber air minum layak perdesaan sebesar $65,81 \%$ dan untuk perkotaan sebesar $75,29 \%$ atau rata-rata 68,87\% (Anonim, 2010). Disebutkan pula pada laporan tersebut bahwa, tantangan berat pencapaian target MDGs sektor air minum meliputi kuantitas, kualitas, kontinuitas, aspek pendanaan yang meliputi sumber dana, struktur tarif dan keterjangkauan, pelayanan kaum miskin, manajemen, dan kelembagaan.

Sumber air untuk pelayanan air minum oleh Perusahaan Daerah Air Minum (PDAM) di Kota Kupang dan sekitarnya, berasal dari air tanah (sumur bor) dengan persentase 60\%, mata air 38\%, dan hanya 2\% berasal dari sungai (Anonim 2012; Anonim 2014 ${ }^{\mathrm{a}}$ ), tidak termasuk kapasitas produksi dari sumber air Waduk Tilong. Data ini menunjukkan ketergantungan yang tinggi terhadap pemakaian air tanah dan masih sangat kecil pemanfaatan air permukaan. Eksploitasi berlebihan terhadap air tanah tidak hanya menyebabkan pengurangan ketersediaan air tetapi juga berakibat bagi penurunan kualitas air (Malik dan Shimi, 2014), dan menyebabkan terjadi intrusi air asin ke dalam air tawar (Nasjono, 2010). Sehubungan dengan hal tersebut maka, upaya yang lebih efisien dari pengelolaan sumber daya air yang tersedia mutlak diperlukan (Cresswel dan Naser, 2013), termasuk melaksanakan program konservasi dan penekanan pada pengurangan pemakaian air perkotaan (Devitt dan Morris, 2010). Penyediaan air minum juga dipengaruhi oleh banyak faktor termasuk pola konsumsi masyarakat yang dipengaruhi oleh keadaan sosial, budaya dan ekonomi (Kim dkk., 2007). Strategi pemenuhan kebutuhan air minum di daerah yang memiliki keterbatasan kapasitas sumber air, dapat dilakukan dengan cara minimalisir penggunaan air domestik (rumah tangga) yang boros dengan fasilitas publik yang dapat dimanfaatkan bersama (Halper dkk., 2000).

Kajian pemenuhan kebutuhan air minum dalam penelitian ini dibatasi pada lingkup identifikasi potensi sumber air baku yang tersedia, dan skenario pemenuhan kebutuhan air minum. Identifikasi potensi sumber air baku dalam penelitian ini akan didasarkan pada potensi dari sumber air tanah, air permukaan dan pemanfaatan potensi air hujan dengan pembuatan waduk. Potensi sumber air baku melalui proses desalinasi, daur ulang dan sumber lainnya tidak turut diperhitungkan. Penelitian oleh Zaghloul dan AlMutairi (2010) menyebutkan bahwa, masyarakat perkotaan di Kuwait lebih menunjukkan dukungan penggunaan air dari potensi air hujan yang ada dibandingkan dengan air limbah daur ulang.

Sehubungan dengan penjelasan yang ada sebelumnya, maka tujuan penelitian ini adalah menganalisis strategi pemenuhan kebutuhan air minum bagi masyarakat di Kota Kupang dan sekitarnya yang termasuk dalam kawasan semi-arid Indonesia, tahun 2015-2035. Kajian pemenuhan kebutuhan air minum dalam penelitian ini dilakukan dengan sistem regional (lintas wilayah administratif), atau dikenal dengan Sistem Penyediaan Air Minum (SPAM) Regional. Pertimbangannya adalah efektivitas dan efisiensi pelayanan air minum kepada masyarakat dan merupakan salah satu alternatif untuk mengatasi terbatasnya sumber air baku di beberapa kabupaten/kota, sementara di beberapa wilayah lain dalam satu provinsi terdapat potensi air baku yang cukup (Anonim, 2014 ). 


\section{METODE PENELITIAN}

\section{Waktu dan Lokasi}

Penelitian dilaksanakan dari bulan JuliDesember 2014. Penelitian dilaksanakan di wilayah administrasi Kota Kupang dan sekitarnya yang termasuk dalam wilayah Kabupaten Kupang, selanjutnya disebut Regional Kupang dalam konteks pengembangan SPAM. Wilayah adminsitrasi Kota Kupang meliputi enam kecamatan yaitu: Alak, Maulafa, Oebobo, Kelapa Lima, Kota Raja dan Kota Lama. Wilayah Kabupaten Kupang meliputi empat kecamatan, yakni Kecamatan Kupang Barat, Kupang Tengah, Nekamese dan Taebenu (Gambar 1).

\section{Sumber Data dan Prosedur}

Data yang digunakan adalah hasil survei sumber air baku di Regional Kupang, data kependudukan, data fasilitas-fasilitas umum dan sosial, rencana umum tata ruang wilayah (RTRW) Kota Kupang dan Kabupaten Kupang, dan data lainnya yang relevan. Teknik pengumpulan data dilakukan melalui dokumentasi formal terhadap data-data terkait yang dilengkapi dengan hasil survei lapangan untuk mengetahui kondisi riil ketersediaan dan pengelolaan air minum di daerah studi. Penelitian dilakukan dalam tiga tahap, yakni tahap pertama melakukan perhitungan proyeksi jumlah penduduk dengan pendekatan statistik dan proyeksi laju kebutuhan air minum tahun 20152035. Tahap kedua melakukan identifikasi potensi sumber air minum dan kapasitas sumber air yang bisa dimanfaatkan, serta tahap ketiga melakukan skenario pemenuhan kebutuhan air minum di Regional Kupang tahun 2015-2035.

\section{Analisis Data}

Proyeksi jumlah penduduk didasarkan atas laju perkembangan kota dan kecenderungannya, arahan tata guna lahan serta ketersediaan lahan untuk menampung perkembangan jumlah penduduk. Metode proyeksi pertumbuhan penduduk berdasarkan metode ekstrapolasi matematis yakni: rata-rata aritmatik, least square, geometrik, dan regresi linear. Metode terpilih adalah yang memiliki simpangan baku terkecil. Data kependudukan pada daerah studi adalah data dari tahun 2000 sampai tahun 2012 dari Badan Pusat Statistik Republik Indonesia. Perhitungan proyeksi fasilitas umum dan sosial dilakukan terhadap fasilitas: pendidikan, peribadatan, kesehatan, perkantoran, perdagangan, olah raga dan budaya, serta industri. Perhitungan berdasarkan perbandingan jumlah penduduk acuan dengan jumlah fasilitas yang sudah ada, sesuai

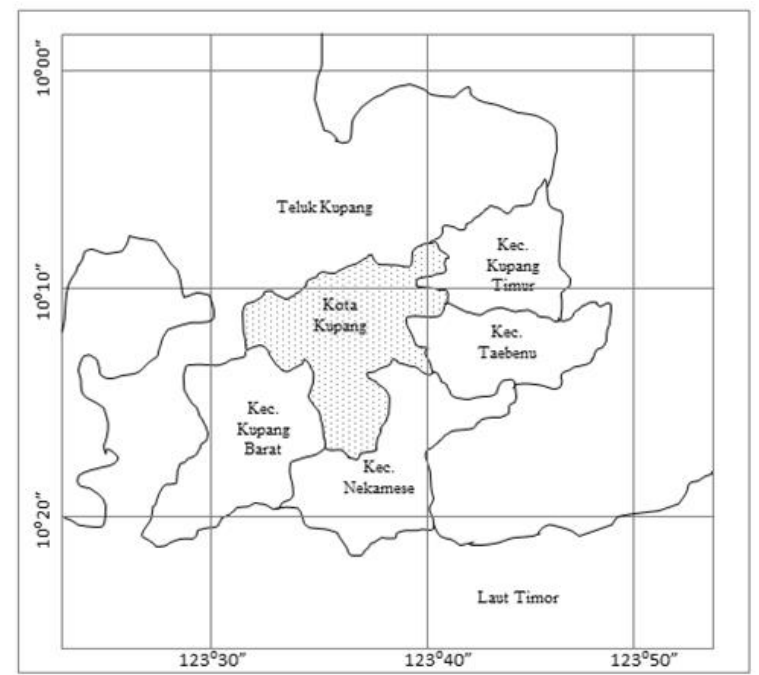

Gambar 1. Lokasi penelitian di Regional Kupang.

ketentuan standar fasilitas perkotaan DPU-Cipta Karya (Anonim, 2002), dengan rumus:

$J U T P=J U T S+\frac{(J P T P-J P T S)}{S M T P F}$

di mana, JUTP adalah jumlah unit tahun proyeksi, JUTS adalah jumlah unit tahun sebelumnya, JPTP adalah jumlah penduduk tahun proyeksi (jiwa), JPTS adalah jumlah penduduk tahun sebelumnya (jiwa), dan SMPTPF adalah standar minimal tersedianya pendukung fasilitas (Anonim, 2002).

Proyeksi laju kebutuhan air minum dilakukan untuk kebutuhan air domestik (rumah tangga), kebutuhan non-domestik (fasilitas sosial dan umum), kebutuhan perkotaan (pemadam kebakaran dan taman kota), dan kehilangan air. Kebutuhan air domestik direncanakan akan terlayani oleh sambungan langsung rumah tangga (SR) dan hidran umum (HU), dengan persentase jangkauan pelayanan $80 \%$ melalui SR dan $20 \%$ melalui $\mathrm{HU}$. Kebutuhan air non-domestik dilakukan dengan mengacu pada proyeksi jumlah fasilitas nondomestik dan standar kebutuhan air non-domestik sesuai standar kebutuhan air minum (Anonim, 2003).

Proyeksi kebutuhan air minum di Regional Kupang dilakukan dengan cara berikut. Pertama adalah penetapan persentase jangkauan pelayanan air minum dari jumlah penduduk yang ada. Target jangkauan pelayanan tahun 2015 sebesar 68,86\% sesuai target MDGs, dan mulai akhir tahun 2019 sampai tahun 2035 jangkauan pelayanan air minum adalah $100 \%$ sesuai arah kebijakan pembangunan di sektor air minum (Anonim, 2014 ${ }^{\mathrm{b}}$ ). Selanjutnya, menghitung kebutuhan air domestik, menghitung kebutuhan air non-domestik, menghitung kehilangan air akibat proses produksi dan kebocoran sebesar 20\% dari total kebutuhan air 
domestik dan non-domestik, menghitung kebutuhan air rata-rata yang merupakan jumlah kebutuhan air domestik, non-domestik dan kehilangan air. Kebutuhan air maksimum diperoleh dari faktor 1,10 dikalikan kebutuhan air rata-rata. Perhitungan kebutuhan air perkotaan terdiri dari kebutuhan pemadam kebakaran yang ditetapkan sebesar 5\% dari kebutuhan air maksimum, serta kebutuhan tata kota (pertamanan) sebesar 10\% dari kebutuhan air minimum. Kebutuhan air total adalah kebutuhan air maksimum ditambah kebutuhan air perkotaan. Tahapan perhitungan yang terakhir adalah kebutuhan air jam puncak yang diperoleh dari faktor 1,20 dikalikan dengan kebutuhan air total.

Kajian strategi pemenuhan kebutuhan air minum dilakukan dengan dua skenario. Skenario pertama berdasarkan optimalisasi potensi sumber air yang teridentifikasi di daerah studi, meliputi sumber air alami (air tanah, mata air, sungai), dan sumber air hasil pengembangan sumber daya air (waduk). Skenario kedua adalah skenario ideal yang dibangun dengan asumsi bahwa, potensi sumber air tersedia sesuai dengan kebutuhan perencanaan. Pengambilan asumsi dengan alasan yang baik dan tepat diperlukan untuk menyelesaikan persoalan hidrologi secara praktis (Viessman dkk., 1989), oleh karena itu simplifikasi skenario tersebut dilakukan untuk dapat memberikan solusi secara praktis.

\section{HASIL DAN PEMBAHASAN}

Kawasan semi-arid adalah kawasan yang identik dengan kekeringan, disebabkan karena masalah keterbatasan dalam hal kuantitas dan kontinuitas air dari sumber air untuk pemenuhan kebutuhan air multisektor, khususnya air minum. Regional Kupang sebagai kawasan semi-arid di Indonesia, juga mengalami tantangan dalam hal penyediaan akses air minum layak bagi masyarakatnya. Pertumbuhan penduduk dan aktivitas pembangunan yang tinggi, semakin memperbesar tantangan dimaksud. Untuk itu diperlukan strategi dalam rangka pengelolaan sumber daya air yang tersedia dalam rangka pemenuhan kebutuhan air bagi masyarakat. Strategi dan arah pengembangan SPAM dalam penelitian ini dilakukan untuk masa 20 tahun, yakni tahun 2015-2035 sesuai dengan jumlah penduduk dan kategori wilayah.

\section{Gambaran Pelayanan Air Minum di Daerah Studi}

Regional Kupang termasuk dalam wilayah administratif Provinsi Nusa Tenggara Timur (NTT), di mana Provinsi NTT merupakan salah satu dari 34 provinsi di Indonesia saat ini. Luas wilayah Kota Kupang adalah 180,27 km², jumlah penduduk tahun 2012 adalah 365.348 jiwa, dengan kepadatan penduduk $2.027 \mathrm{jiwa} / \mathrm{km}^{2}$ (Anonim, $\left.2013^{\mathrm{a}}\right)$. Luas wilayah empat kecamatan di Kabupaten Kupang adalah 473,18 $\mathrm{km}^{2}$ dengan jumlah penduduk tahun 2012 adalah 80.291 jiwa dan kepadatan penduduk adalah $170 \mathrm{jiwa} / \mathrm{km}^{2}$ (Anonim, 2013 $3^{\mathrm{b}}$ ).

Pihak PDAM selaku operator air minum, lebih banyak memanfaatkan air baku dari sumber air tanah dibanding air permukaan (sungai). Cakupan pelayanan PDAM dari SPAM jaringan perpipaan pada tahun 2012 mencapai 48,46\% (Anonim, 2012; Anonim, 2014 ${ }^{\mathrm{a}}$ ), dengan tingkat kebocoran sebesar 28\% (Anonim, 2013 ${ }^{\mathrm{C}}$ ). Sebanyak 51,54\% jumlah penduduk yang belum terlayani melalui SPAM jaringan perpipaan, memenuhi kebutuhan air minum melalui air kemasan, air isi ulang, mata air tak terlindungi, sumur tak terlindung dan sumber lainnya (Anonim, 2013ª Anonim, 2013 ). Dari hasil observasi di daerah studi, suplai air minum melalui SPAM jaringan perpipaan belum berjalan dengan kontinyu dan masih terjadi penggiliran. Pada musim kemarau panjang sejumlah sumber air dari sumur bor dan mata air mengalami pengurangan debit yang sangat besar bahkan mengalami kekeringan. Dari data Master Plan Air Bersih Kota Kupang tahun 2006 (Adoe, 2008), tercatat bahwa debit musim kemarau pada 19 sumber air di Kota Kupang hanya tersisa sekitar $11 \%$ dibanding debit pada saat musim penghujan.

\section{Laju Permintaan Air Minum di Regional Kupang}

Berdasarkan jumlah penduduk, persentase pelayanan, penduduk terlayani, tingkat kehilangan air, kebutuhan air non-domestik, kebutuhan perkotaan dan fluktuasi kebutuhan air oleh masyarakat, dapat diketahui jumlah kebutuhan air di daerah studi sebagaimana ditunjukkan Tabel 1. Dari data dasar tahun 2012 dibandingkan terhadap data proyeksi tahun 2035, jumlah penduduk akan bertambah dari 445.639 jiwa menjadi 971.643 jiwa atau mengalami peningkatan $118 \%$. Kebutuhan air minum meningkat dari kondisi kapasitas produksi eksisting $353 \mathrm{~L} /$ det di tahun 2012 menjadi 2.632 L/det di tahun 2035 atau mengalami peningkatan sebesar 646\% di tahun 2035.

Pada tahun 2012, akses pelayanan air minum mencapai 48,46\% setara dengan 215.917 jiwa terlayani air minum (Anonim, 2012; Anonim, 2013 ${ }^{\mathrm{c}}$, Anonim, 2014 ). Untuk mencapai target MDGs 2015 sebesar 68,87\% dengan skema pemenuhan kebutuhan air minum melalui SPAM jaringan perpipaan, dibutuhkan peningkatan jang- 
Tabel 1. Kebutuhan air minum di Regional Kupang (tahun 2015-2035).

\begin{tabular}{|c|c|c|c|c|c|c|}
\hline \multirow[t]{2}{*}{ Uraian } & \multirow[t]{2}{*}{ Satuan } & \multicolumn{5}{|c|}{ Proyeksi kebutuhan air minum } \\
\hline & & 2015 & 2020 & 2025 & 2030 & 2035 \\
\hline Jumlah penduduk & Jiwa & 493.331 & 584.427 & 692.345 & 820.190 & 971.643 \\
\hline Persentase pelayanan & $\%$ & 69 & 100 & 100 & 100 & 100 \\
\hline Penduduk terlayani & jiwa & 339.757 & 584.427 & 692.345 & 820.190 & 971.643 \\
\hline Kebutuhan domestik & L/det & 554 & 852 & 1.115 & 1.321 & 1.564 \\
\hline Kebutuhan non-domestik & L/det & 85 & 100 & 119 & 141 & 170 \\
\hline $\begin{array}{l}\text { Kebutuhan domestik + non- } \\
\text { domestik }\end{array}$ & L/det & 638 & 953 & 1.233 & 1.462 & 1.734 \\
\hline \multirow{2}{*}{ Kehilangan air } & $\%$ & 20 & 20 & 20 & 20 & 20 \\
\hline & L/det & 128 & 191 & 247 & 292 & 347 \\
\hline Kebutuhan air rata-rata & L/det & 766 & 1.143 & 1.480 & 1.754 & 2.081 \\
\hline \multirow{2}{*}{ Kebutuhan air maksimum } & faktor & 1,10 & 1,10 & 1,10 & 1,10 & 1,10 \\
\hline & $\mathrm{L} / \mathrm{det}$ & 843 & 1.257 & 1.628 & 1.930 & 2.289 \\
\hline Pemadam kebakaran & L/det & 84 & 126 & 163 & 193 & 229 \\
\hline Tata kota & L/det & 42 & 63 & 81 & 96 & 114 \\
\hline Kebutuhan air total & L/det & 969 & 1.446 & 1.872 & 2.219 & 2.632 \\
\hline \multirow[t]{2}{*}{ Kebutuhan air jam puncak } & faktor & 1,20 & 1,20 & 1,20 & 1,20 & 1,20 \\
\hline & L/det & 1.011 & 1.509 & 1.954 & 2.316 & 2.747 \\
\hline
\end{tabular}

Sumber: Hasil analisis penelitian.

kauan pelayanan 20,41\% dengan penambahan 16.507 SR dan $248 \mathrm{HU}$. Untuk mencapai target aman pelayanan air minum $100 \%$ pada akhir tahun 2019, dibutuhkan peningkatan jangkauan pelayanan 51,54\% dengan penambahan 75.327 SR dan 1.130 HU. Jumlah SR dan HU akan semakin bertambah hingga tahun 2035 seiring dengan pertumbuhan penduduk. Jika mengikuti skema 60\% SPAM jaringan perpipaan dan 40\% SPAM bukan jaringan perpipaan untuk mencapai target pelayanan $100 \%$ pada tahun 2019 (Anonim, 2014 ), maka beban PDAM akan menjadi lebih ringan, namun tanggung jawab Pemerintah untuk menyediakan akses air minum 40\% dengan SPAM bukan jaringan perpipaan akan mendapat tantangan berat pada daerah semi-arid yang memiliki keterbatasan sumber air.

Mencermati laju permintaan air minum yang tinggi tersebut maka, perlu dilakukan kajian strategi pemenuhan laju permintaan air minum di Regional Kupang untuk jangka waktu 2015-2035, yang oleh Donkor dkk. (2014) menyebutkan terdapat ketidakpastian dalam perkiraan permintaan di masa mendatang. Meskipun demikian, strategi dan integrasi perencanaan dan penyelenggaraan pembangunan air minum wajib dilakukan dalam perspektif mengamankan penyediaan air minum sehingga dapat memenuhi aspek kualitas, kuantitas, kontinuitas, dan keterjangkauan (Arwin, 2009).

\section{Potensi Sumber Air di Regional Kupang}

Potensi sumber air yang ada di Regional Kupang untuk dikembangkan melalui SPAM jaringan perpipaan, maksimal sebesar $1.354 \mathrm{~L} /$ det, berasal dari sumber air alami (mata air, air tanah dan sungai), serta sumber air hasil pengembangan sumber daya air yakni waduk dan rencana waduk. Sumber air Waduk Tilong dari kapasitas produksi saat ini $150 \mathrm{~L} /$ det untuk 8 jam per-hari dapat dikembangkan menjadi maksimal 350 L/det (Messakh dkk., 2012). Potensi sumber air dari waduk yang berpeluang diperoleh pada jangka panjang adalah dari rencana Waduk Kolhua dengan alokasi air baku untuk air minum sebesar $151 \mathrm{~L} /$ det. Potensi sumber air berikutnya berasal dari optimalisasi sumber air yang dikelola PDAM dengan memanfaatkan potensi kapasitas sumber air sebesar $676 \mathrm{~L} /$ det, dengan rincian mata air 405 L/det, sumur bor 256 L/det (dari Cekungan Air Tanah/CAT) dan sungai 15 L/det, (Anonim, 2012; Anonim, 2013 ${ }^{\mathrm{c}}$; Anonim, 2014 ). Potensi air tanah yang bisa dimanfaatkan sekitar 433 L/det (Banunaek, 2002; Pasaribu dkk., 2013) dan yang belum dimanfaatkan oleh PDAM sebesar 177 L/det. Menurut Pasaribu dkk. (2013) CAT Kupang secara geografis berada dalam batas garis $123^{\circ} 27^{\prime} 24,48^{\prime}$ BT dan 123 $56^{\prime} 31,56^{\prime \prime}$ BT serta garis lintang $10^{\circ} 00^{\prime} 12,66^{\prime}$ LS dan $10^{\circ} 21^{\prime} 45,37^{\prime}$ ' LS yang meliputi wilayah administratif Kabupaten Kupang dan Kota Kupang dengan luas sekitar 758,3 km². Keberadaan potensi CAT di daerah studi karena lapisan batuan di Pulau Timor mempunyai penyebaran karakteristik koral limestone dan Formasi Bobonaro yang tercampur dengan clay stone dengan usia tersier di bagian barat laut. Koral limestone (karang) sangat porous dan lapisan batuan ini sangat dominan di Pulau Timor.

Potensi sumber air lainnya adalah dari sumur gali yang dimiliki oleh masyarakat yang terdata sebanyak 3.100 buah, dan umumnya melayani 


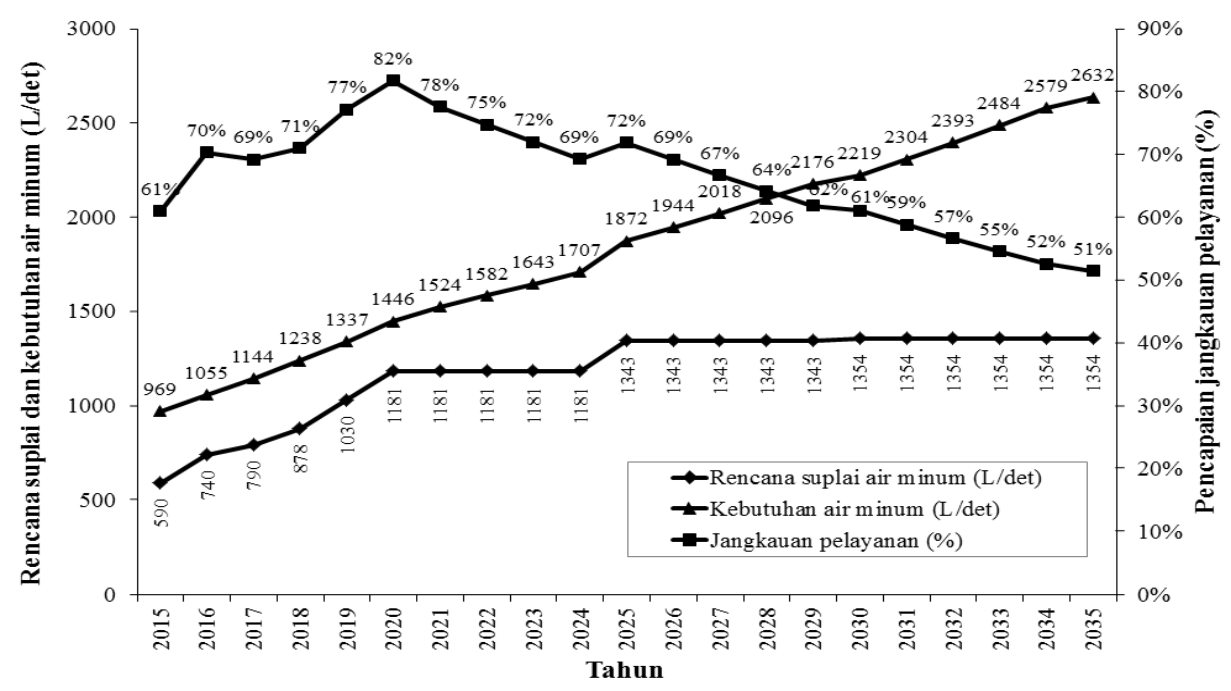

Gambar 2. Skenario pemenuhan kebutuhan air minum di Regional Kupang berdasarkan potensi sumber air tersedia, tahun 2015-2035.

kebutuhan air untuk tiga sampai 15 rumah tangga (Adoe, 2008). Variabilitas debit yang tinggi menyebabkan banyak sumur yang mengalami kekeringan pada musim kemarau. Kondisi ini semakin diperparah dengan perubahan tata guna lahan pada kawasan konservasi yang berfungsi sebagai ruang hidrologi menjadi kawasan terbangun. Akibatnya adalah kualitas, kuantitas dan kontinuitas air minum dari sumur gali menjadi tidak terjamin. Untuk itu potensi ini tidak dimasukkan ke dalam skenario utama penyediaan air minum, dan akan sebagai pelengkap jika skenario melalui SPAM jaringan perpipaan belum dapat menjangkau pelayanan kepada seluruh masyarakat.

\section{Strategi Peningkatan Jangkauan Pelayanan Air Minum Berdasarkan Potensi Sumber Air}

Gambar 2 menunjukkan hasil kajian skenario pemenuhan kebutuhan air minum di Regional Kupang tahun 2015-2035 dengan SPAM jaringan perpipaan, berdasarkan potensi ketersediaan air dari sumber air yang teridentifikasi. Peningkatan kapasitas produksi air baku untuk air minum menunjukkan trend meningkat pada jangka menengah pertama tahun 2015-2019 yakni mencapai $77 \%$ jangkauan pelayanan, dan tahun 2020 mencapai maksimal 80\%. Setelah itu jangkauan pelayanan cenderung menurun dan hanya akan mencapai persentase $51 \%$ pada tahun 2035. Hal ini disebabkan karena kapasitas produksi dari sumber air terbatas jumlahnya, sedangkan laju permintaan air semakin meningkat akibat pertumbuhan penduduk dan aktivitas pembangunan.

Melalui skenario ini dapat diketahui bahwa pemenuhan kebutuhan air minum di Regional
Kupang tidak dapat dilayani sepenuhnya dengan SPAM jaringan perpipaan. Target MDGs tahun 2015 sebesar 68,87\% akses masyarakat terhadap air minum, akan tercapai maksimal sebesar 61\% melalui SPAM jaringan perpipaan dan sisanya $7,87 \%$ melalui SPAM bukan jaringan perpipaan. Pada akhir tahun 2019, 23\% kekurangan jangkauan pelayanan melalui SPAM jaringan perpipaan harus terlayani melalui SPAM bukan jaringan perpipaan. Pada tahun 2035, jangkauan pelayanan hanya mencapai 51\% dengan SPAM jaringan perpipaan dan sisanya $49 \%$ harus terlayani dengan SPAM bukan jaringan perpipaan. SPAM bukan jaringan perpipaan, diharapkan akan terlayani diantaranya melalui sumur gali yang dimiliki masyarakat yang memenuhi syarat air yang layak minum dan aman untuk dikonsumsi, serta terjamin kontinuitasnya. Tantangannya adalah sebagaimana dipaparkan pada bagian sebelumnya bahwa, kurang adanya jaminan kuantitas, kualitas dan kontinyuitas air baku dari sumur gali masyarakat. Secara nasional, target aman pencapaian pelayanan air minum pada akhir tahun 2014 adalah 70,05 \% dan untuk mencapai target 100\% tahun 2019 masih dibutuhkan peningkatan jangkauan pelayanan 29,95\% (Anonim, 2014 ${ }^{\mathrm{b}}$ ).

\section{Strategi Ideal Pemenuhan Kebutuhan Air Minum}

Skenario ini dibangun dengan asumsi tersedianya sumber air sesuai kapasitas yang dibutuhkan dalam rangka pengembangan SPAM jaringan perpipaan untuk mencapai jangkauan pelayanan $100 \%$ akses air minum layak bagi masyarakat mulai akhir tahun 2019. Strategi pengembangan yang dilakukan adalah sebagaimana 
ditunjukkan pada Gambar 3. Pada pengembangan tahun 2015, direncanakan penambahan kapasitas terpasang sebesar $855 \mathrm{~L} /$ det sehingga kapasitas terpasang mencapai $1.208 \mathrm{~L} /$ det. Dari kebutuhan sebesar 969 L/det maka, terdapat kelebihan kapasitas terpasang sebesar 239 L/det sebagai angka aman perencanaan untuk memenuhi kebutuhan masyakarat dalam rentang waktu 20152019. Pada periode pengembangan 2015-2019, terdapat area bertanda positif yang terjadi pada tahun 2015 sampai pertengahan tahun 2017, dan area bertanda negatif pada pertengahan tahun 2017 sampai akhir tahun 2019. Area bertanda positif menunjukan kelebihan kapasitas terpasang dibanding laju permintaan air minum, namun dalam pengoperasiannya tetap dilakukan produksi sesuai kebutuhan dalam rangka efisiensi. Area bertanda negatif menunjukan kapasitas terpasang tidak mencukupi laju kebutuhan air minum sehingga pemenuhan kebutuhan air minum diharapkan melalui SPAM bukan jaringan perpipaan.

Kondisi break event point akan terjadi pada pertengahan tahun 2017. Kondisi yang sama akan terjadi pada tahapan-tahapan pengembangan berikutnya dari tahun 2020-2035. Kondisi break event point diharapkan menjadi titik dimulainya kegiatan perencanaan pengembangan SPAM periode berikutnya. Strategi ini membutuhkan investasi dana yang besar pada setiap awal pengembangan SPAM per-periode lima tahunan. Meskipun demikian, strategi ini dapat menjadi salah satu alternatif untuk dipilih dengan alasan efisiensi penganggaran dan efektivitas dalam pelaksanaan pekerjaan di lapangan jika dilihat dalam horizon waktu pengembangan SPAM jangka panjang 15-20 tahun. Untuk mencapai rencana pengembangan pada setiap periode pengembangan lima tahunan, maka sudah harus dilakukan tahapan perencanaan sampai pelaksanaan pembangunan jaringan air minum, yanni survey, investigation, design, construction, operation dan maintenance.

\section{Upaya Peningkatan Jangkauan Pelayanan Air Minum Jangka Panjang}

Dari potensi ketersediaan sumber air baku dan proyeksi kebutuhan air minum periode 2015-2035, diketahui bahwa pemenuhan kebutuhan air minum di Regional Kupang akan menghadapi tantangan yang besar untuk mencapai target pelayanan 100\%. Pemanfaatan air tanah dalam persentase terbesar di daerah studi dibandingkan dengan pemanfaatan air permukaan (sungai), disebabkan karena masalah kualitas, kuantitas, kontinuitas dan keterjangkauan. Masalah kuantitas dan kontinuitas disebabkan karena variabilitas debit yang tinggi pada saat musim penghujan yang singkat (tiga sampai empat bulan), yakni air terdapat dalam jumlah yang banyak bahkan menyebabkan banjir. Pada saat musim kemarau panjang (delapan sampai sembilan bulan), debit sungai dan mata air jauh berkurang, bahkan tidak ada aliran permukaan (Messakh dkk., 2013).

Pengembangan sumber daya air melalui pembangunan waduk, embung atau wadah penampungan air hujan lainnya, merupakan salah satu solusi memanfaatkan potensi curah hujan yang

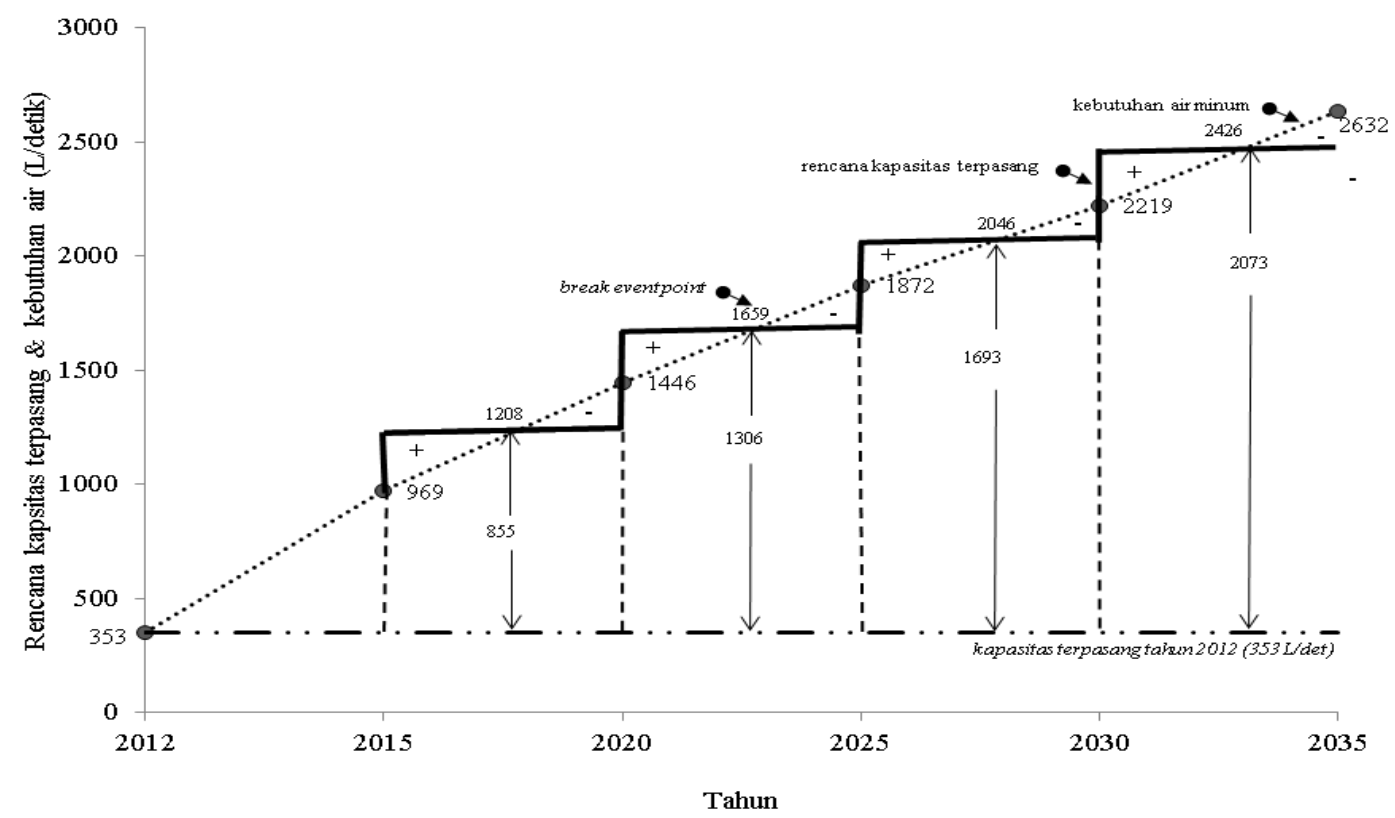

Gambar 3. Pemenuhan kebutuhan air minum di Regional Kupang berdasarkan skenario ideal, tahun 20152035. 
terjadi sekitar $1500 \mathrm{~mm}$ per-tahun (Messakh dkk., 2013), dan hanya 7-29\% air hujan yang terinfiltrasi ke dalam tanah (Banunaek, 2002). Padahal, pada daerah karst ketersediaan air tanah akan bergantung kepada curah hujan yang terjadi (Arsyad dkk., 2014). Apabila potensi hujan di daerah studi tidak dimanfaatkan maka, ketersediaan air tanah dalam jangka panjang yang dieksploitasi secara terusmenerus akan menjadi terancam. Malik dan Shimi (2014) menyebutkan bahwa, pemanfaatan air tanah secara berlebih akan menimbulkan banyak dampak negatif bagi lingkungan. Padahal yang terjadi di daerah studi adalah pengendalian pemanfaatan air bawah tanah masih terdesak oleh prioritas pemenuhan kebutuhan masyarakat akan air bersih.

Upaya menggerakkan peran serta masyarakat dalam penyediaan air minum untuk memenuhi kebutuhannya, dinilai akan memberikan kontribusi nyata terhadap target pencapaian pelayanan air minum 100\% pada akhir tahun 2019, dibanding upaya sendiri oleh Pemerintah. Syahrani dkk. (2004) menyebutkan bahwa, tingkat partisipasi masyarakat cukup tinggi dalam pengelolaan air ketika masyarakat diikut-sertakan. Dalam rancangan teknokratik RPJMN 2015-2019 disebutkan bahwa sasaran pengembangan prasarana air minum untuk meningkatkan akses masyarakat terhadap pelayanan air minum ditetapkan dengan pola penanganan melalui pembangunan SPAM di kawasan masyarakat berpenghasilan rendah, ibu kota kecamatan, desa, kawasan khusus, dan regional, membangun penampung air hujan (PAH), melakukan fasilitasi optimasi bauran sumber daya air domestik di kota metropolitan dan kota besar, fasilitasi PDAM sehat, fasilitasi business to business, fasilitasi restrukturisasi utang PDAM, peningkatan jumlah PDAM sehat (Anonim, 2014). Hal ini mengandung makna bahwa, upaya pencapaian target pemenuhan kebutuhan air minum bagi masyarakat haruslah merupakan upaya bersama dari Pemerintah (pusat dan daerah), masyarakat, badan usaha dan PDAM.

Strategi pemenuhan kebutuhan air minum di daerah semi-arid melalui SPAM jaringan perpipaan, perlu dilakukan melalui upaya penentuan prioritas pelayanan air minum dengan pertimbangan tata ruang wilayah yang ada. Penentuan prioritas dengan memperhatikan nilai strategis wilayah dan jumlah dan kepadatan penduduk, maka wilayah administratif Kota Kupang sebagai pusat pemerintahan, kawasan perdagangan, pusat pendidikan, kawasan pemukiman dengan intensitas tinggi (82\% jumlah penduduk Regional Kupang) akan mendapat prioritas. Berikutnya adalah wilayah Kabupaten Kupang sebagai wilayah penyangga Kota Kupang, kawasan pemukiman dengan intensitas rendah sampai sedang dengan jumlah penduduk sebesar $18 \%$ dari jumlah penduduk Regional Kupang. Memperhatikan kondisi sebaran pemukiman di daerah studi sesuai hasil observasi dan pertimbangan kondisi pendanaan PDAM yang masih sangat terbatas (Anonim, 2013c), maka prioritas pelayanan air minum di Regional Kupang dapat dilakukan dengan clustering and cost strategies (Anonim, 1974), yang memberi penekanan sekecil mungkin biaya pengadaan sistem perpipaan. Dipilih area dan tata bangunan yang kompak atau tidak terpencar agar investasi yang diberikan dapat dimanfaatkan secara maksimum. Daerah dengan konsentrasi penduduk dan pemukiman yang terpencar, strategi pemenuhan kebutuhan air minum dapat dilakukan melalui pemasangan $\mathrm{HU}$ atau SPAM bukan jaringan perpipaan.

\section{KESIMPULAN}

Sumber air utama untuk pemenuhan kebutuhan air minum di Regional Kupang melalui SPAM jaringan perpipaan berasal dari sumber air tanah (sumur bor, sumur gali) dan mata air. Alasan kualitas, kuantitas, kontinuitas dan keterjangkauan, menyebabkan pemanfaatan air permukaan belum menjadi prioritas. Pemanfaatan curah hujan di daerah studi dengan cara pembuatan waduk, atau wadah penampungan air hujan lainnya, akan menjadi potensi sumber air baku untuk memenuhi laju kebutuhan air minum yang sangat tinggi. SPAM bukan jaringan perpipaan dapat dilakukan melalui sumur gali masyarakat bila memenuhi syarat kualitas air minum dan memiliki kuantitas dan kontinuitas yang terjamin.

Penghematan penggunaan air sesuai kebutuhan dan kearifan lokal daerah, serta pengaturan prioritas daerah pelayanan untuk SPAM jaringan perpipaan, merupakan strategi berikutnya yang bisa dilakukan. Selanjutnya, perlu perubahan paradigma bagi para stakeholder terkait dalam pengelolaan sumber daya air di daerah studi, dengan pemahaman akan kekhasan daerah sebagai kawasan semi-arid, sehingga dalam hal penentuan kebijakan dan pengaturan distribusi air untuk kebutuhan multisektor memperhatikan prinsip berbagi air, dengan prioritas adalah air minum untuk masyakarat.

Konservasi sumber daya air mutlak diperlukan dalam rangka keberlanjutan ketersediaan air di daerah studi. Potensi wilayah yang memiliki cekungan air tanah, merupakan faktor penting yang akan menjadi nilai tambah bila dikelola dengan baik dalam rangka keberlanjutan pengelolaan sumber daya air. Apabila tindakan-tindakan 
konservasi tidak diperhatikan maka, target pencapaian pelayanan air minum di Regional Kupang, akan semakin sulit diwujudkan.

\section{DAFTAR PUSTAKA}

Adoe, T.H.R., 2008. Pengendalian Pemanfaatan Air Bawah Tanah di Kota Kupang. Tesis Pasca Sarjana, Magister Teknik Pembangunan Wilayah dan Kota, Universitas Diponegoro Semarang.

Anonim, 1974. Village Water Supply and Sanitation in Less Developed Countries. The International Bank for Reconstruction and The International Development Association (IBRD-IDA), Washington.

Anonim, 1989. Arid Zone Forestry: A Guide for Field Technicians. Food Agriculture Association (FAO), Rome.

Anonim, 2002. Standar Fasilitas Perkotaan. Direktorat Cipta Karya-Departemen Pekerjaan Umum Republik Indonesia, Jakarta.

Anonim, 2003. Standar Kebutuhan Air Minum. Departemen Pemukiman dan Prasarana Wilayah Republik Indonesia, Jakarta.

Anonim, 2010. Peta Jalan Percepatan Pencapaian Tujuan Pembangunan Milenium di Indonesia. Badan Perencanaan Pembangunan Nasional, Jakarta.

Anonim, 2011. Global Drylands: A UN System Wide Respons. United Nations Environment Management Group, New York.

Anonim, 2012. Laporan Bulanan PDAM Kabupaten Kupang Bulan Juni 2012. PDAM Kabupaten Kupang, Kupang.

Anonim, 2013 ${ }^{\mathrm{a}}$. Kabupaten Kupang Dalam Angka 2012. Badan Pusat Statistik Kabupaten Kupang, Kupang.

Anonim, 2013 . Kota Kupang Dalam Angka 2012. Badan Pusat Statistik Kota Kupang, Kupang.

Anonim, 2013'. Kinerja PDAM 2013-Wilayah IV Papua, Maluku, NTB, NTT, Bali. Badan Pendukung Penyembangan Sistem Penyediaan Air Minum Kementerian Pekerjaan Umum Republik Indonesia, Jakarta.

Anonim, 2014 . Corporate Plan PDAM Kota Kupang 2014- 2018. PDAM Kota Kupang, Kupang.

Anonim, 2014 ${ }^{\mathrm{b}}$. Rancangan Teknokratik RPJMN 2015-2019. Kementerian Pekerjaan Umum Republik Indonesia, Jakarta.

Arsyad, M., Pawitan, H., dan Sidauruk, P., 2014. Analisis Ketersediaan Air Sungai Bawah Tanah dan Pemanfaatan Berkelanjutan di Kawasan Karst Maros Sulawesi Selatan. Jurnal Manusia dan Lingkungan, 21(1):8-14.
Arwin, 2009. Perubahan Iklim, Konversi Lahan dan Ancaman Banjir dan Kekeringan di Kawasan Terbangun. Pidato Guru Besar di Majelis Guru Besar ITB Bandung, disampaikan pada Rapat Majelis Guru Besar ITB Bandung, 27 Februari 2009.

Banunaek, N., 2002. Potensi dan Dampak Pemanfaatan Airtanah Terhadap Masyarakat Kota Kupang, Seminar Pengembangan dan Pemberdayaan Konsumen Jasa Konstruksi. YPKJI, Kupang.

Cresswell, M,. dan Naser, G., 2013. A Water Resources Management Strategy for Small Water District - A Case Study of the South East Kelowna Irrigation District. Canadian Journal of Civil Engineering, 40(1):499-507.

Devit, D., dan Morris, R., 2010. Sustainable Water Use in Urban Landscapes in the $21^{\text {st }}$ Century: a Las Vegas Perspective. Acta Horticulturae, 881(1):483-486.

Donkor, E.A, Mazzuchi T.A., Soyer, R, dan Roberson, J.A., 2014. Urban Water Demand Forecasting: Review of Methods and Models. Journal of Water Resources Planning and Management, 140(2):146-159.

Halper, E.B., Dall'erba, S., Bark, R.H., Scott, C.A., dan Yool, S.R., 2015. Effects of Irrigated Parks on Outdoor Residential Water Use in A Semi-arid City. Landscape Urban Planing Journal, 134(1) 210-220.

Kim, S.H., Choi, S.H., Koo, J.Y., S.I. Choi, S.I., dan Hyun, I.H., 2007. Trend Analysis of Domestik Water Consumption Depending Upon Sosial, Cultural, Economic Parameters. Water Science and Technology Water Supply, 7(5-6):61-68.

Malik, N., dan Simi, N.S., 2014. Effect of Urbanization on Groundwater Quality in the Gafsa Town South Western Tunisia. Desalination and Water Treatment, 52(1012):2022-2031.

Messakh, J.J., Arwin, dan Hadihardaja, I.K., 2012. Climate Change and Strategy of Reservoir Operation In Semi-Arid Area, West Timor. International Proceeding: The $3^{\text {rd }}$ International Seminar on Sustainable Urban Development. Jakarta. Pp. 78-88.

Messakh, J.J., Arwin, Hadihardaja, I.K., dan Duppe, Z., 2013. Impact of Climate Change on Hydrology Regime and Sustainability of Water Availability in Semi-Arid Region, West Timor. International Proceeding: Book 3 The Second International Conference on Sustainable Infrastructure and Built Environment. Bandung. Pp. 91-101. 
Nasjono, J.K., 2010. Pola Penyebaran Salinitas Pada Aquifer Pantai Pasir Panjang, Kota Kupang, NTT. Jurnal Bumi Lestari, 10(2):263-269.

Pasaribu, M., Wahyudin, dan Soeharti, I., 2013. Evaluasi Potensi Air Tanah Cekungan Air Tanah, Provinsi NTT. Situs : http://pag.bgl. esdm.go.id/

Syahrani, Legono, D., dan Nurrochmad, F., 2004. Analisis Peranserta Masyarakat Dalam
Pengeloaan Air Bersih. Jurnal Manusia dan Lingkungan, 11(2):86-95.

Viessman, W.Jr., Lewis, G.L., dan Knapp, J.W., 1989. Introduction to Hydrology, 3rd Ed. Harper and Row Publisher, Inc., Illinois, p312.

Zaghloul, N.A., dan Al-Mutairi, B.L., 2010. Water Harvesting of Urban Runoff in Kuwait. Scientia Iranica, 17(3A):236-243. 